\title{
Ideological and Political Design and Practice of Hydrology and Water Resources Curriculum based on Blending Learning
}

\author{
Jinfeng Wang, Wen Dai \\ Liupanshui Normal University, School of Tourism and Historical Culture, Liupanshui, Guizhou, \\ 553004, China
}

\begin{abstract}
Curriculum ideological and political is a breakthrough and new starting point for the establishment of morality in colleges and universities, and is an effective way to train socialist builders and successors. We mainly take the geographical science professional course "Hydrology and Water Resources" as an example, starting with the curriculum ideological and political design concept, design ideas, teaching implementation and effects, and discussing the strategy of developing curriculum ideological and political under the online and offline mixed teaching mode, and It analyzes the methods in detail and methods of integrating political identity, professional ethics, professional literacy, scientific exploration spirit, dialectical thinking, scientific and cultural literacy, environmental protection awareness and other ideological and political elements before, during and after class, and implements the goal of training geography teachers to achieve the purpose of educating people for the party and educating talents for the country. Through a questionnaire survey of the 2019 students of geographic science class, the result shows that the ideological and political design and practice of hydrology and water resources courses based on the online and offline hybrid teaching of Chaoxing Xuetong have been highly praised by the students.
\end{abstract}

Keywords: Blending Learning; Hydrology and Water Resources; Curriculum Reform.

\section{Introduction}

Ideological and Political Courses refers to the formation of synergy between various courses and ideological and political theory courses in the form of building a whole staff, whole process and whole ideological and political education pattern. Its essence is to integrate ideological and political education into all links and aspects of curriculum teaching and reform, so as to achieve the goal of establishing moral integrity in cultivation[1]. Essentially speaking, its purpose is to realize morality and cultivate Curriculum ideological and political is a breakthrough and a new starting point for the establishment of morality in colleges and universities, and is an effective way to train socialist builders and successors. It is helpful to improve the comprehensive quality of students and promote the comprehensive development of students' morality, intelligence, physical education, and labor [2]. The main form of curriculum ideological and political education is to integrate the elements of ideological and political education into various courses, which will have a certain impact on students' ideology and behavior [3]. Ideological and political education includes not only the theoretical knowledge and political concepts of ideological and political education, but also ethics, values, ideological understanding and spiritual pursuits. In the view of this, colleges and universities should actively and deeply undertake this important responsibility and carry out ideological and political courses and curriculum ideological and political. In the course of professional course teaching, ideological and political elements are incorporated, and the correct concept of country, nation, history, and culture is subtly established in the hearts of contemporary students, so as to solve the problem of 'what kind of person to cultivate' and 'how to cultivate people'.

Hydrology and water resources is a compulsory basic course for geography science majors, a preface course for soil geography and plant geography, and a core course for devoloping geography teachers in middle schools. Through this course, students will analyze the causes and effects of hydrological phenomena and retell the concepts of surface water, groundwater, precipitation, infiltration, water vapor transportation, evaporation, runoff, and water resources. They can use their own language to describe the mechanism of water cycle and flow generation, understand the frontiers of water science, be able to use the principle of water cycle to judge various hydrological phenomena, 
analyze their influencing factors and their results, and be able to design questions about hydrological knowledge in middle school geography. Finally, let they form a correct teacher's professional ethics, have a scientific attitude that respects facts, strives for perfection, and is rigorous and realistic, and has the mission of geography education given to middle schools by the times. The course is rich in content and contains a large number of ideological and political elements, but the teaching hours are limited, and the majors are combined with liberal arts and sciences. The basic gap of students is too large, and students cannot carry out repeated learning of their own difficult knowledge and ideological and political elements. How to effectively carry out curriculum ideology and politics in the teaching process of hydrology and water resources is a brand-new topic before teachers. In the view of this, the authors propose the ideological and political course of hydrology and water resources based on blending learning, deeply excavates the ideological value and spiritual connotation contained in the professional knowledge system of hydrology and water resources, and scientifically and rationally expands the breadth, depth and temperature of the course. And they insist on establishing themselves by virtue, learning by virtue, and teaching by virtue, guiding students to establish a correct world outlook, outlook on life and values, focusing on strengthening the inheritance and innovation of Chinese excellent traditional culture, and cultivating morality, intelligence, physical education, and comprehensive services for the society. Developed talents train qualified builders and reliable successors for the cause of socialism with Chinese characteristics.

\section{Ideological and Political Design Ideas}

\subsection{Design Concept}

As the old saying goes, "Teachers preach and teach karma to solve puzzles." The primary purpose of teachers in educating students is to "preach", that is, to teach students the principles of life. Morality is the foundation of being a person. "Educating people" must first "educate morality". Ideological and political education is the work of being a person. It is necessary to pay attention to the organic unity of preaching, teaching, and cultivating talents, and comprehensively promote the curriculum ideological and political construction. Curriculum ideological and political is not a simple "course" plus "ideological and political" [4], the organic integration of professional knowledge and moral education content, mutual promotion and coordinated development, from the outside to the inside, from the near and far, and attracting people to the country's feelings, ethics, values, ideological understanding, spiritual pursuit, The historical changes in the social system and the historical achievements of the country are naturally integrated into all aspects of the curriculum to achieve a quiet teaching effect.

\subsection{Design Ideas}

The ideological and political design of hydrology and water resources courses takes patriotism as the main line, and continuously optimizes the supply of ideological and political teaching content of the curriculum around key knowledge such as political identity, professional ethics, professional literacy, scientific exploration spirit, dialectical thinking, scientific and cultural literacy, and environmental awareness. The ideological and political design of the course utilizes information technology to make full use of online and offline carriers to integrate with each other, integrate the inside and outside of the classroom, and the obvious and hidden elements to naturally penetrate the ideological and political elements into all aspects of the curriculum, and generate emotional resonance and understanding with students, and realize the internal The teaching effect of turning to the heart, externalizing to the action, and moisturizing the things silently. Online integration of related subject development history, historical background, deeds of Chinese and foreign celebrities, examples or current events, actual cases, etc. into hydrology and water resources knowledge points, stimulate students' initiative and enthusiasm in learning, and continuously improve students' ability to discover and solve problems. Offline integrate online ideological and political content into classroom learning through positive education, finishing touches, discipline restraint, and implicit penetration [5], so as 
to achieve the purpose of preaching, teaching and deciphering, educating people and cultivating talents through preaching and deeds. At the same time, it integrates materials containing ideological and political elements into homework, discussion and communication. When students read material analysis questions, discuss and speak, they subtly and naturally internalize ideological and political elements into students' exploration, thinking and comprehension.

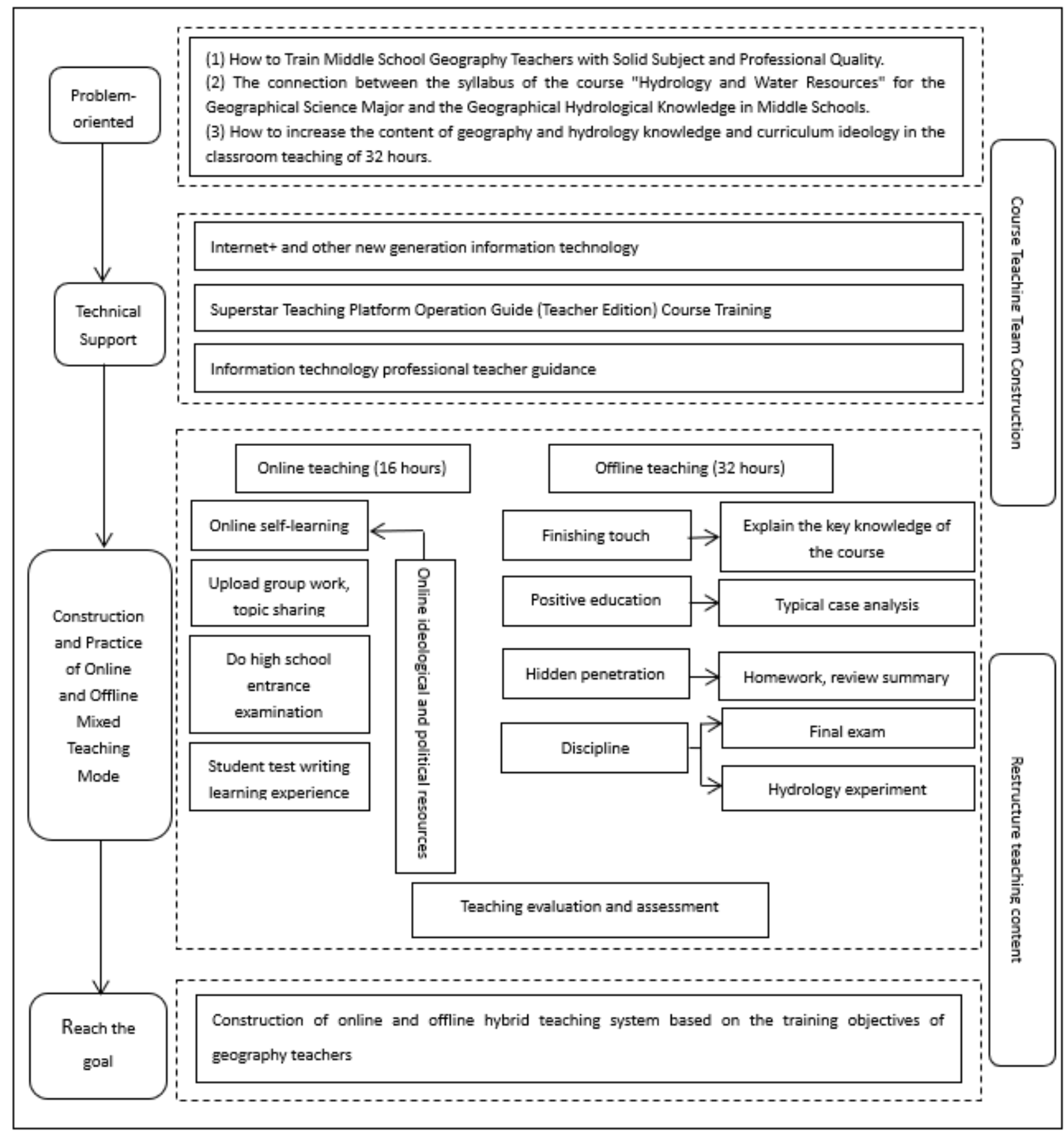

Fig 1. Incorporating curriculum ideology into the blending learning system

\section{Ideological and Political Implementation}

\subsection{Pushing Online Ideological and Political Resources before Class}

According to the characteristics and advantages of geography disciplines, in-depth study of the educational goals of geography sciences, in-depth exploration of the ideological value and spiritual connotation contained in the hydrology and water resources courses, and scientifically and rationally 
expand the breadth, depth and depth of the hydrology and water resources courses temperature. By analyzing the support of hydrology and water resources courses to the graduation requirements of geography sciences, summarizing and refining the goals of hydrology and water resources courses, combining quality goals, selecting content and ideological materials that meet the ideological and political content of online teaching courses from the teaching content.

Table 1. The main content and ideological and political integration points of hydrology and water resources course

\begin{tabular}{|c|c|c|c|}
\hline $\begin{array}{c}\text { Serial } \\
\text { number }\end{array}$ & $\begin{array}{l}\text { Course } \\
\text { Contents }\end{array}$ & $\begin{array}{l}\text { Ideological and political } \\
\text { integration point }\end{array}$ & $\begin{array}{c}\text { Material } \\
\text { presentation } \\
\text { form }\end{array}$ \\
\hline 1 & $\begin{array}{l}\text { The history of the } \\
\text { discipline }\end{array}$ & $\begin{array}{l}\text { My country's great water conservancy project } \mathrm{Du} \\
\text { jiangyan, the design and construction of this project } \\
\text { fully demonstrated the wisdom and foresight of the } \\
\text { ancient people of our country, and cultivated students' } \\
\text { sense of national identity, sense of responsibility, } \\
\text { historical self-confidence and patriotism. }\end{array}$ & Video \\
\hline 2 & $\begin{array}{l}\text { Distribution of } \\
\text { water and water } \\
\text { resources on the } \\
\quad \text { earth }\end{array}$ & $\begin{array}{l}\text { By telling the total amount of water resources in } \\
\text { our country, the characteristics of temporal and spatial } \\
\text { distribution, and the main problems, students are trained } \\
\text { to gradually form a sense of social responsibility and } \\
\text { mission to save water and protect water resources, and } \\
\text { promote water conservation and protection of water } \\
\text { resources for the whole people. }\end{array}$ & Tell \\
\hline 3 & $\begin{array}{l}\text { Rivers, water } \\
\text { systems and } \\
\text { watersheds }\end{array}$ & $\begin{array}{l}\text { The "Talking about the Yangtze River" video } \\
\text { shows the deep and vast Yangtze River and the } \\
\text { unremitting perseverance of the scientific research } \\
\text { personnel to explore the true source of the Yangtze } \\
\text { River, cultivate students' scientific spirit of lofty } \\
\text { ambition and the pursuit of true knowledge, and inspire } \\
\text { students' sense of science and technology to serve the } \\
\text { country and their mission. }\end{array}$ & Video \\
\hline 4 & $\begin{array}{l}\text { The hydrological } \\
\text { situation of the } \\
\text { river }\end{array}$ & $\begin{array}{l}\text { The advanced deeds of flood fighting and disaster } \\
\text { relief in } 1998 \text { in the Yangtze River Basin guided } \\
\text { students to intuitively experience the occurrence and } \\
\text { development of floods, grasp the essence of flood } \\
\text { fighting spirit, and inspire students to carry forward the } \\
\text { spirit of responsibility and dedication. }\end{array}$ & Case \\
\hline 5 & $\begin{array}{l}\text { Overview of the } \\
\text { water cycle }\end{array}$ & $\begin{array}{l}\text { "Discuss whether water resources are } \\
\text { inexhaustible", "Discuss the rationality of introducing } \\
\text { Bohai into Xinjiang" and other topics, train students to } \\
\text { use Marxist dialectical principles to develop multi- } \\
\text { dimensional thinking, analyze the versatility of things, } \\
\text { and cultivate the future The overall view of decision } \\
\text { makers. }\end{array}$ & Discuss \\
\hline 6 & Run-off & $\begin{array}{l}\text { "Discuss the impact of human activities on runoff, } \\
\text { especially the impact of urbanization on runoff and peak } \\
\text { flow", exercise students' divergent thinking, train } \\
\text { students to have the ability to integrate and apply } \\
\text { knowledge, and to take a comprehensive view of } \\
\text { problems and the sense of ownership of scientific } \\
\text { decision-making. Have a global view of future decision } \\
\text { makers. }\end{array}$ & Case \\
\hline 7 & $\begin{array}{l}\text { Lakes, swamps and } \\
\text { glaciers }\end{array}$ & $\begin{array}{l}\text { A systematic introduction to the current situation, } \\
\text { causes and hazards of the ecological environment of } \\
\text { lakes and swamps in my country, as well as the } \\
\text { countermeasures of ecological environmental protection }\end{array}$ & Literature \\
\hline
\end{tabular}




\begin{tabular}{|c|c|c|c|}
\hline & & $\begin{array}{l}\text { and restoration, to guide students to have a deep } \\
\text { understanding of the profound significance of the } \\
\text { thoughts on ecological civilization construction since } \\
\text { the 18th National Congress of the Communist Party of } \\
\text { China, and to have a deep understanding and } \\
\text { understanding of General Secretary Xi Jinping The } \\
\text { profound meaning of the theory of "green water and } \\
\text { green mountains are also golden mountains and silver } \\
\text { mountains" actively cultivates the concept of ecological } \\
\text { civilization of students. }\end{array}$ & \\
\hline 8 & $\begin{array}{l}\text { Distribution and } \\
\text { classification of } \\
\text { oceans }\end{array}$ & $\begin{array}{l}\text { "Caring for the ocean like life", "caring for the } \\
\text { ocean, knowing the ocean, and managing the ocean", } \\
\text { "developing ocean economy and ocean scientific } \\
\text { research", "building a powerful modern navy", } \\
\text { "community with a shared future for the ocean" and } \\
\text { other "sea spirit" Encourage students, train them to learn } \\
\text { and love the sea, and inspire students to shoulder the } \\
\text { mission of building a maritime power. }\end{array}$ & $\begin{array}{c}\text { Classic } \\
\text { quotations }\end{array}$ \\
\hline 9 & $\begin{array}{l}\text { Type of } \\
\text { groundwater }\end{array}$ & $\begin{array}{l}\text { The positive and negative heads of confined water and } \\
\text { whether the Baotu Spring of Jinan is discharged in the } \\
\text { form of fountains, guide students to understand the } \\
\text { professional knowledge of the characteristics of } \\
\text { confined water, stimulate students' love for my country's } \\
\text { great rivers and mountains, and cultivate students' } \\
\text { understanding of resource regulation The necessity. }\end{array}$ & Case \\
\hline 10 & $\begin{array}{l}\text { Water resources } \\
\text { and water quality }\end{array}$ & $\begin{array}{l}\text { Establish and practice the concept that green waters and } \\
\text { green mountains are golden mountains and silver } \\
\text { mountains, adhere to the harmonious coexistence of } \\
\text { man and nature, adhere to the path of peaceful } \\
\text { development, and promote the construction of a } \\
\text { community with a shared future for mankind }\end{array}$ & Literature \\
\hline
\end{tabular}

Online teaching uses virtual space as the carrier, and the middle circle focuses on the third classroom of network ideological and political. Through online education, we can realize the linkage education with the offline first classroom, and promote the "dual improvement" of students' ideological and professional qualities. Hydrology and water resources courses rely on the Chaoxing learning platform to build an online and offline hybrid teaching system. And according to the course syllabus and course teaching progress, the learning resources closely related to hydrology and water resources knowledge points are released before class (Table 1). Mainly in the form of videos, narrations, cases, discussions, literature, classic quotations to stimulate students' interest in learning, actively think, and expand reading. In the process of self-learning before class, he is deeply affected by ideological and political influence, so as to cultivate professional talents in the basic research and teaching of geography science with the comprehensive development of morality, intelligence, physical education, art and labor for the society.

\subsection{Ideological and Political Integration in the Curriculum}

Based on the opinions of group discussions, exchanges, and speeches in class, students use the discussion area of Chaoxing Learning Communication Platform to express their personal feelings or thoughts, supplement materials related to ideological and political content, and conduct re-learning and re-discussions. For example, when studying the overview of the water cycle, students in the preclass class completed discussions, exchanges, and speeches on topics such as "discussing whether water resources are inexhaustible" and "discussing the rationality of introducing Bohai into Xinjiang". After class, apart from sharing my thoughts and insights on Marxist dialectical principles, I can also discuss the question "From the perspective of water pollution speed exceeding the purification load, 
do you think water can be fully regenerated?" These questions can guide students to explore the advantages and disadvantages of weighing the pros and cons, and make the most advantageous strategic choices, so as to inspire students to attach importance to dialectical thinking. At the same time, they are required to be good at dealing with the relationship between local and overall, current and long-term, key and non-key points, use dialectical thinking to grasp strategic planning, and consciously adhere to and use dialectical materialist world outlook and methodology. Through the online and offline hybrid teaching model, ideological and political education is naturally and effectively integrated into classroom teaching, making the education system more scientific, threedimensional and concrete.

\section{Implementation Effect}

Ideological and political education is an innovation with rich connotation and lofty intention, which integrates the factors of ideological and political education into the curriculum, enriches the connotation of professional courses, excavates its educational value and expands its educational and teaching functions [6].In order to understand the effect of the ideological and political implementation of the curriculum, for the ideological and political design and implementation of the hydrology and water resources curriculum, the questionnaire is used to find out the students' Political identity, professional ethics, professional literacy, scientific exploration spirit, dialectical thinking, scientific and cultural literacy, environmental awareness and other aspects of education under the hybrid teaching mode. According to the five-level scoring standard, students have achieved good results in political identity, professional ethics, professional literacy, scientific exploration spirit, dialectical thinking, scientific and cultural literacy, and environmental awareness. Among them, $87 \%$ of students believe that political identity, professional ethics, dialectical thinking, and environmental awareness have a greater impact. It shows that the ideological and political design and practice of hydrology and water resources courses based on the online and offline hybrid teaching of Chaoxing Learning Communication have been highly evaluated and widely praised by the 2019 students of Geography.

In addition, since the national, provincial, and school launching first-class courses, hydrology and water resources have been approved and completed for school-level excellent courses, and at the same time, they have been approved and completed for provincial-level first-class courses. In 2021, it is proposed to be recommended to apply for the country's second batch of online and offline mixed firstclass courses. After the evaluation by the school supervisors, the enlightening teachers and students of the hydrology and water resources courses, the integration of the course ideology and politics into nature, and the active and in-depth classroom discussions were highly praised by the supervisors and left a deep impression. The course team won the first prize and the second prize of the school-level young teacher science and engineering group teaching competition once.

The students majoring in geography science bear the heavy burden of geography teaching in middle school. In the process of undergraduate study in colleges and universities, college teachers should master the design and implementation of ideology and politics, and have the awareness and ability of " ideology and politics". In different teaching environments, they use different teaching methods and correctly guide students to establish a correct world outlook, values and outlook on life. The teaching of hydrology and water resources courses is based on understanding the requirements of teacher professional certification, and further explores the ideological and political education resources of the course in the course construction. This course combines curriculum professional knowledge with ideological and political elements, and explores the combination of teaching content and ideological and political elements. In terms of teaching methods and means, reform methods are proposed, and teaching and educating people are put into the main channel of classroom teaching to provide references for the ideological and political education of geography science major courses. 
Volume 3 (2021)

\section{Acknowledgments}

This study was supported by the Guizhou teaching content and curriculum system reform project (2020187) and Undergraduate teaching engineering project of Liupanshui Normal University (lpss yjxtd201805).

\section{References}

[1] Gao Deyi, Zong Aidong. From ideological and political course to ideological and political course: constructing the curriculum system of Ideological and political education in Colleges and universities from a strategic height [J]. China Higher Education, 2017, (1):43-46.

[2] Gao Deyi, Zong Aidong. Curriculum ideology: the inevitable choice to effectively play the role of the main channel of classroom education [J]. Journal of Ideological and Theoretical Education, 2017, (1): 3134.

[3] Wang Xuejian, Shi Yan. The connotation, characteristics, difficulties and coping strategies of the ideological and political curriculum in the new era[J]. Journal of Xinjiang Normal University (Philosophy and Social Sciences Edition), 2020, 41(2): 50-58.

[4] Xu Tao. Constructing the educational pattern of curriculum ideology and politics. Guangming Daily. [2019-10-18]. http://epaper.gmw.cn/gmrb/ html/2019-10/18 /nw. D110000gmrb_20191018_3 -15.htm.

[5] Dai Jun, Li Xianpeng, Li Zhihua, et al. Design and practice of "Curriculum Ideology" in medical immunology adapted to online hybrid teaching [J]. Chinese Journal of Immunology, 2020, 36(18): 2275 $-2278$.

[6] Dao Kun Lu. Some core Problems and Solutions in the implementation of ideological and political Courses: Discussion based on ideological and political courses of professional courses[J]. Ideological \& Theoretical Education,2018(03): 64 -69. 